\title{
Biologická příbuznost jedinců ze satelitních pohřebišt' Pohanska u Břeclavi ve světle analýzy nemetrických znaků
}

\author{
Biological kinship estimation of the individuals found at the side \\ cemeteries of Pohansko near Břeclav based on non-metric traits analysis
}

\section{Anna Koudelková}

\begin{abstract}
Abstrakt
Nemetrické znaky jsou dědičnými kosterními anomáliemi, které se s různě nízkými frekvencemi přirozeně vyskytují v každé lidské populaci. Ačkoliv jsou hojně využívány pro mezipopulační srovnání již od 60. let 20. století, k rozšíření jejich využití pro analýzu příbuznosti jedinců doposud př́liš často nedochází. Tento článek představuje možnosti využití analýzy nemetrických znaků pro intrapopulační srovnání na př́kladu 49 zkoumaných jedinců, pohřbených v oddělených skupinkách na satelitních pohřebištích v sídlištním kontextu raně středověké lokality Pohanska u Břeclavi. U všech jedinců bylo hodnoceno 162 nemetrických znaků a kromě jejich vizuálního posouzení byly výsledky objektivizovány výpočtem koeficientu potenciální př́buznosti (hodnotí vždy míru pravděpodobné př́buznosti dvou jedinců), který je v této studii blíže představen. Předpokládaná interpretační hypotéza satelitních pohřebišt', jako skupin biologicky př́buzných jedinců, byla v hodnoceném vzorku potvrzena pouze pro skupinu z polohy Lesní hrúd.
\end{abstract}

\section{Klíčová slova}

Nemetrické znaky, epigenetické znaky, Pohansko u Břeclavi, př́buznost, raný středověk, koeficient potenciální príbuznosti

\begin{abstract}
Non-metric traits are heritable skeletal anomalies that occur naturally in every human population, with population-specific frequencies. Although they have been used for inter-population comparisons since the 1960s, their application as a tool to investigate kinship is not widely accepted yet. This study explores further possibilities of using non-metric traits analysis for intra-population analysis by examining 49 individuals buried in separate groups on the early medieval site of Pohansko near Břeclav. These so-called satellite cemeteries were located directly in the settlement area and they have been considered family burials. Apart from the visual assessment, the results obtained by the analysis of 162 non-metric traits in each individual have been evaluated using the potential kinship coefficient (introduced in this study), which sets an estimation of potential family relationship between two individuals. In the analysed sample, the hypothesis of biological family buried together as a group has only been confirmed with the group from Lesni hrúd (Forest Dune) site.
\end{abstract}




\section{Keywords}

Non-metric traits, epigenetic traits, Pohansko near Břeclav, kinship, family relationships, Early Middle Ages, potential kinship coefficient

Práce vznikla za podpory projektu MUNI/A/0930/2018 „Archeologické terénní prospekce, exkavace, dokumentace a muzejní prezentace VIII"

\section{1. Úvod}

Raně středověká lokalita Pohansko se nachází asi $2 \mathrm{~km}$ jižně od města Břeclavi uprostřed obory Soutok u Břeclavi (obr. 1). Systematický archeologický výzkum zde probíhá již od 50. let 20. století pod vedením ústavu archeologie a muzeologie Masarykovy univerzity (Macháček 2005, 27), a byl při něm odkryt zatím jen zlomek předpokládané plochy velkomoravského hradiska a jeho zázemí. Plocha byla prozkoumána po menších částech a tyto jednotlivé polohy se mezi sebou výrazně liší, co do zástavby i předpokládané interpretace jejich využití.

Předkládaná studie se zabývá jedinci pohřbenými v tzv. satelitních pohřebištích. Jde o hroby, které nebyly uloženy v rámci běžného pohřebiště, ale formovaly menší skupiny přímo v sídlištním areálu. Cílem práce bylo zjištění, zda jde ve skupinách i mezi nimi o jedince biologicky př́ibuzné, a zda je toto zjištění vůbec v možnostech současné antropologie bez využití analýz DNA.

Hodnocené kosterní pozůstatky byly odkryty v polohách Lesní hrúd, Lesní školka (obě byly součástí ohrazeného areálu) a Jižní a Severní předhradí (vyznačeno na obr. 2, podle Přichystalová 2011, 13).

\section{1. Úvod do studia nemetrických znaků}

Pravděpodobná příbuznost jedinců ze satelitních pohřebišt Pohanska byla stanovována pomocí analýzy nemetrických znaků na kosterních pozůstatcích. Nemetrické znaky (tj. epigenetické, diskrétní či kvazi-kontinuální znaky - jde vždy pouze o jiný název pro stejnou množinu) byly zkoumány již od 20. let 20. století, přičemž k zásadnímu rozvoji v jejich výzkumu došlo v 50. a 60. letech 20. století. Mezi prvními většími propagátory tohoto směru bádání byl například Hans Grüneberg (Grüneberg 1952, týž 1963), manželé Berryovi (Berry - Berry 1967), M. Suzuki a T. Sakai (Suzuki - Sakai 1960), N. S. Ossenbergová (Ossenberg 1969) a A. Czarnetzki (Czarnetzki 1971). Stěžejní prací moderní doby je publikace badatelů Hauserové a De Stefana (Hauser - De Stefano 1989) a v českém prostředí zejména práce Petra Velemínského - at již samotného (Veleminský 1999, týž 2000), či ve spolupráci s dalšími autory (Veleminský - Dobisiková 2005, Veleminský - Likouský 2013).

\subsubsection{Definice}

Za nemetrické znaky mohou být považovány takové morfologické anomálie na kostře, které splní následující kritéria: vysoká dědivost, nízká frekvence výskytu v populaci, nízká závislost na věku a pohlaví zkoumaného jedince a nízká meziznaková korelace (Reinhard - Rösing 1985). Zjednodušeně jsou tedy souborem znaků, které jsou odlišné od anatomického standardu, jsou geneticky determinovány, a zároveň mají nízký výskyt v běžné populaci. Právě díky těmto vlastnostem mohou tyto variety docela dobře 


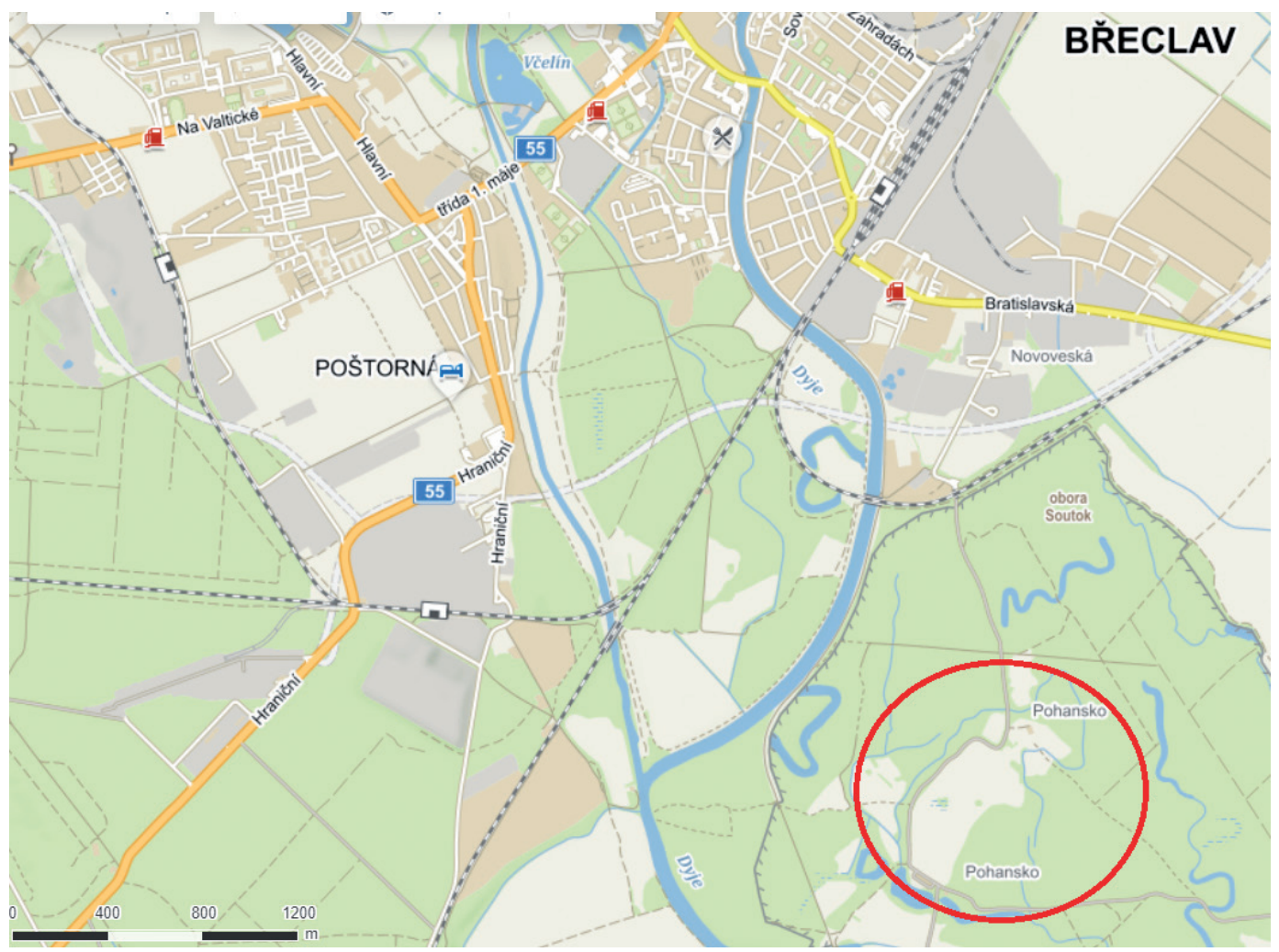

Obr. 1: Pohansko u Břeclavi. (mapy.cz).

Fig. 1: Pohansko near Břeclav (mapy.cz)

indikovat biologické vztahy mezi jedinci i mezi populacemi navzájem. Množina známých a používaných nemetrických znaků je tvořena stovkami znaků na celé lidské kostře, přičemž nejvíc jich můžeme najít na lebce (Veleminský - Likovský 2013, 231).

\subsubsection{Dědičnost nemetrických znaků}

Ačkoliv je povědomí o existenci nemetrických znaků rozšířeno mezi odbornou veřejností poměrně dlouho, mechanismus jejich dědičnosti u lidí není zatím úplně objasněn. Dosavadní znalosti se zakládají na historických genetických studiích zkoumajících myší populace a pozdější verifikaci takto získaných informací na známých sbírkách lidských koster. Při studiu myší se zjistilo, že žádný ze znaků nevykazuje prostou mendelovskou dědičnost, a vždy je určen komplexem genů uložených na více lokusech. Projev znaku ve fenotypu dále ovlivňují kromě vnitřních faktorů i faktory vnější. Základním problémem při posuzování genetických vztahů mezi subjekty je míra ovlivnění projevu znaku vnějšími podmínkami, nebot nelze předpokládat, že by dva různí jedinci byli vystaveni totožným vnějším podmínkám po celou dobu svého života, a že by po celou dobu probíhaly v organismech totožné procesy. Tyto problémy bere v úvahu dědivost (= heritabilita), který vyjadřuje podíl genetické složky vůči vlivům vnějšího i vnitřního prostředí na projevu znaku.

Analogie dědičnosti znaků u myší se znaky u člověka byla stanovena zejména na základě 


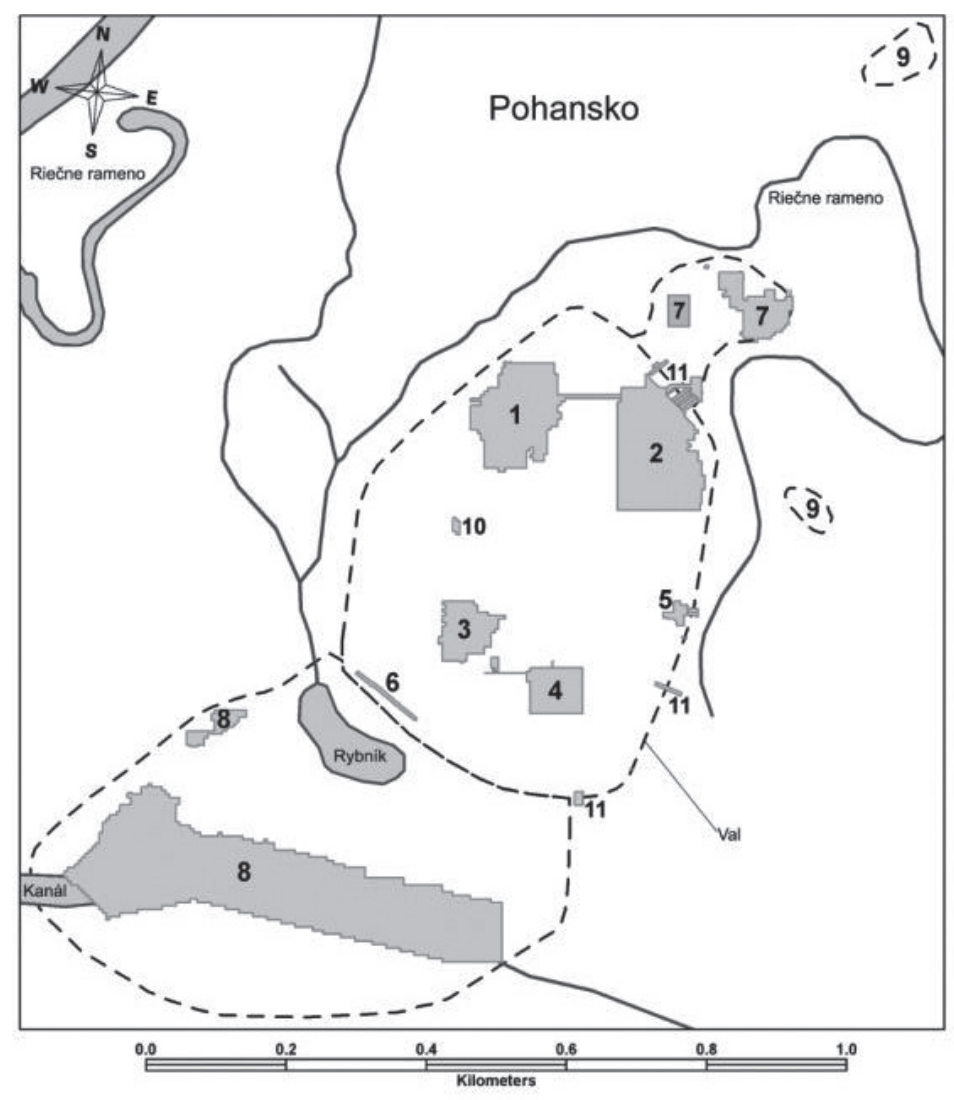

Obr. 2: Mapa areálu. 2 - Lesní školka; 4 - Lesní hrúd; 7 - Severní předhradí; 8 -Jižní předhradí (Přichystalová 2011, 13). Fig. 2: Map of the area. 2 - Forest Nursery; 4 - Forest Dune; 7 - Northern Suburb; 8 - Southern Suburb (Prichystalová 2011, 13).

morfologické podobnosti struktur, které by se tímto způsobem měly dědit, a potvrzena dalšími studiemi (např. Berry - Berry 1967). Část badatelů se i přesto staví k výpovědní hodnotě nemetrických znaků u člověka odmítavě (např. Sjøvold 1984), nebot' nepovažují materiál, na kterém byla verifikace provedena, za dostatečný. Nutno říct, že mnoho koster se známými genetickými vztahy bohužel věda k dispozici nemá, a tak je zde stále široké pole působnosti i pro nové výzkumy (Sedláček 1999, 25-26; Veleminský 1999, 127).
Další výzkumy potvrzující polygenní dědičnost znaků a závislost míry příbuznosti s mírou podobnosti v nemetrických znacích provedli v průběhu let např́klad M. Suzuki a T. Sakai (Suzuki - Sakai 1960), J. Torgersen (Torgersen 1963), S. R. Saundersová a F. Popovich (Saunders - Popovich 1978), R. A. Lane (Lane 1976, týž 1978), P. Velemínský a M. Dobisíková (Veleminský - Dobisiková 2005). Nakonec částečně potvrdil tyto teze i samotný T. Sjøvold, který navzdory svému odmítavému postoji zjistil prokazatelný genetický základ u 14 znaků a jiné 
doporučil pro další studium (Veleminský 1999, 129-130).

Prozatím se ukazuje, že nejlepší model pro dědičnost nemetrických znaků byl stanoven výsledky výzkumů D. S. Falconera (Falconer 1965), který tvrdí, že znaky vykazují polygenní dědičnost, přičemž kódující geny mají aditivní účinky. Znak se ve fenotypu projeví pouze tehdy, jsou-li alely dominantní a v genotypu je dosaženo "prahové hodnoty“ pro projev znaku, která je zároveň ovlivněna i vnějšími faktory. Znamená to, že i dva jedinci s naprosto totožným genotypem (např́ílad jednovaječná dvojčata) se v různém prostředí mohou projevovat rozdílným fenotypem a znak se může, ale také nemusí projevit ( $V e$ leminský 1999, 128).

\section{Materiál a metody}

\subsection{Materiál}

Pro studii pravděpodobné prríbuznosti na satelitních pohřebištích Pohanska bylo analyzováno celkem 57 jedinců. Původně zamýšlený počet 63 nemohl být určen z důvodu špatné dochovanosti materiálu a neexistence některých koster - ty bud' byly kompletně rozloženy již v zemi, anebo byly nenávratně ztraceny $\mathrm{v}$ depozitáŕích v post exkavační fázi zpracování materiálu. Nutno zdůraznit, že jde o materiál z 60. - 80. let 20. století, tudíž lze osud těchto koster jen těžko vystopovat. K závěrečnému vyhodnocení pravděpodobných prríbuzenských vazeb však bylo možné použít jen 49 jedinců, nebot zbývajících 8 bylo $\mathrm{v}$ tak špatném stavu, že u nich nebylo možno pozitivně určit ani jeden znak.

Výběr kosterního materiálu pro analýzu nemetrických znaků byl značně omezen rozsahem diplomové práce, která byla výsledkem těchto analýz. Z velkého množství kosterního materiálu, které máme z Pohanska u Břeclavi stále k dispozici, byli vybráni zejména ti jedinci, u kterých se již předem předpokládalo, že by mohlo jít o př́ibuzné - zejména na základě umístění jejich hrobů v prostoru hradiska i vůči ostatním. Konečný výčet hrobů, použitých k výpočtu koeficientu potenciální prríbuznosti, je zapsán v tab. 1.

U všech jedinců bylo hodnoceno 162 nemetrických znaků, vybraných na základě práce P. Velemínského (Veleminský et al. 2008), který tyto znaky zkoumal u jedinců z lokality Mikulčice-Valy. Snahou tohoto výběru bylo udělat pokud možno analogický výzkum na obyvatelích sousedního hradiska téměř totožného stáří, avšak poněkud odlišného charakteru, a umožnit tak vzájemnou komparaci obou celků v budoucnu.

\subsection{Metody}

\subsubsection{Zkoumání príbuznosti pomocí analýzy nemetrických znaků}

Možnosti antropologie a genetiky při analýze př́ibuznosti degradovaného lidského kosterního materiálu jsou poněkud omezené. Dnes patrně nejpřesnější a za tímto účelem nejvyužívanější analýza aDNA je v případě materiálu déle uskladněného v depozitářích limitována mnoha faktory. Mezi nejvýznamnější patří například špatné uskladnění kosterního materiálu, špatná kvalita odebraného vzorku ( $\mathrm{a} v$ něm nízké procento dochované aDNA) či kontaminace cizí (moderní, méně fragmentární) DNA (Boberová 2012, 18-25). V neposlední řadě jde také o metodu poměrně finančně náročnou, která musí být provedena specializovaným pracovištěm. Oproti tomu je analýza nemetrických znaků pro určení příbuznosti metodou levnou, nenáročnou na vybavení a také rychlou.

Hodnocení kosterních pozůstatků probíhá pouhým okem při použití různě tenkých drátků či inzulinových jehel s tloušt́kou $0,3 \mathrm{~mm}$ pro 


\begin{tabular}{|c|c|c|c|c|c|c|c|}
\hline Poloha & Hrob & Věk [roky] & Pohlaví & Poloha & Hrob & Věk [roky] & Pohlaví \\
\hline \multirow{2}{*}{$J P$} & H0175 & $30-35$ & muž & \multirow{10}{*}{ LS } & $\mathrm{H} 0046$ & $40-50$ & muž \\
\hline & $\mathrm{H} 0176$ & $16-20$ & muž & & $\mathrm{H} 0047$ & 14 & neurčeno \\
\hline \multirow{9}{*}{ LH } & H0013 & 8 & neurčeno & & H0048 & 5 & neurčeno \\
\hline & H0014 & $12-15$ & neurčeno & & $\mathrm{H} 0049$ & $2-4$ & neurčeno \\
\hline & H0015 & $24-30$ & žena & & $\mathrm{H} 0050$ & 12 & neurčeno \\
\hline & H0016 & $20-40$ & žena & & $\mathrm{H} 0051$ & $45-55$ & muž \\
\hline & $\mathrm{H} 0017$ & $24-30$ & žena & & $\mathrm{H} 0052$ & $15-18$ & žena \\
\hline & H0018 & $18-21$ & muž & & $\mathrm{H} 0053$ & $35-40$ & žena \\
\hline & H0019 & $56-65$ & žena & & $\mathrm{H} 0054$ & $35-40$ & muž \\
\hline & $\mathrm{H} 0020$ & 8 & neurčeno & & $\mathrm{H} 0055$ & $55-64$ & muž \\
\hline & $\mathrm{H} 0021$ & $49-58$ & žena & \multirow{14}{*}{ SVP } & $\mathrm{H} 001$ & $30-50$ & žena \\
\hline \multirow{14}{*}{ LS } & $\mathrm{H} 0003$ & 4 & neurčeno & & $\mathrm{H} 002$ & $50-60$ & žena \\
\hline & $\mathrm{HOOO4}$ & 7 & neurčeno & & $\mathrm{HOO3}$ & $60-x$ & žena \\
\hline & H0O05 & 15 & muž? & & $\mathrm{HOO4}$ & $6-7$ & neurčeno \\
\hline & H0006 & 8 & neurčeno & & $\mathrm{H} 005$ & 15 měsíců & neurčeno \\
\hline & $\mathrm{H} 0007$ & $35-40$ & muž & & $\mathrm{H} 006$ & $40-50$ & žena \\
\hline & H0008 & 18 měsíců & neurčeno & & H010a & 2 & neurčeno \\
\hline & H0009 & 7 & neurčeno & & H010b & 2 & neurčeno \\
\hline & H0038 & 3 & neurčeno & & H039 & $40-60$ & muž \\
\hline & $\mathrm{H} 0040$ & $30-35$ & muž & & $\mathrm{HO40}$ & $4,5-5$ & neurčeno \\
\hline & $\mathrm{H} 0041$ & $45-55$ & muž & & $\mathrm{H} 041$ & $60-x$ & muž \\
\hline & $\mathrm{H} 0042$ & 5 & neurčeno & & $\mathrm{HO} 42$ & 5 & neurčeno \\
\hline & $\mathrm{H} 0043$ & 4 & neurčeno & & $\mathrm{HO43}$ & 3 & neurčeno \\
\hline & $\mathrm{H} 0044$ & 3 & neurčeno & & $\mathrm{H} 047$ & $60-x$ & muž \\
\hline & $\mathrm{H} 0045$ & 3 & neurčeno & & & & \\
\hline
\end{tabular}

Tab. 1: Seznam hrobů, u kterých bylo možné zjistit výskyt alespoň jednoho nemetrického znaku. Demografické údaje pro Jižní předhradí, Lesní hrúd a Lesní školku byly převzaty z publikace E Drozdové (Drozdová 2005, 64-67; 69; 104). Tytéž údaje pro Severní předhradí byly prevzaty z publikací B. Dostála (Dostál 1970, 120-124; týž 1982, 169-177) a E. Drozdové (Drozdová 2005, 83-85).

Tab. 1: List of graves with at least one non-metric trait present. Demografic data listed for South suburbium, Lesni hrud and Lesni skolka were taken from E. Drozdova (Drozdová 2005, 64-67; 69; 104). Analogic demographic data for Severni predhradi were taken from B. Dostál (Dostál 1970, 120-124; týž 1982, 169-177) a E. Drozdova (Drozdová 2005, 83-85).

určení prostupnosti otvorů. Jednotlivé znaky jsou určeny definicemi stanovenými $\mathrm{v}$ dílech předešlých badatelů, jako je např. Hauser - De Stefano 1989, či Finnegan 1978. Bohužel může být práce poněkud komplikována nejasností ně- krétním případě hrbolek (tuberculus), prohlu- 
beň (fossa) či kostní val (torus) natolik výrazný, že už jde o projev nemetrického znaku, nebo lze ještě hovořit o anatomicky standardní situaci. Tyto dílčí nedostatky analýzy by mohly být postupně překonány sjednocením metodologie vyhodnocování, konzultacemi mezi odborníky, a hlavně pečlivostí badatele a dokonalou dokumentací, nicméně v momentální situaci poněkud komplikují srovnávání již hodnocených a publikovaných souborů navzájem.

Ačkoliv tedy téma nemetrických znaků bylo v české a slovenské odborné literatuře již několikrát zpracováváno (viz např. Krchová 2004; Hrnčírová 2003; Veleminský - Likovský 2013 a další), a to i pro velkomoravskou populaci, přístup jednotlivých prací se velmi liší. Vesměs jde o práce zaměřené na statistické zpracování nemetrických znaků, bez ohledu na vzájemnou polohu hrobů či archeologický kontext, které jsou využívány spíš pro interpopulační analýzy. Pro srovnání se zde analyzovaným souborem by bylo možné tyto práce použít pouze $\mathrm{z}$ hlediska frekvencí výskytu jednotlivých nemetrických znaků. Ovšem i toto srovnání je značně komplikováno odlišným počtem zkoumaných znaků, a velmi pravděpodobně i rozdílným př́stupem v jejich určování mezi jednotlivými badateli. Jak již bylo zmíněno, definice jednotlivých nemetrických znaků bývají v některých případech poněkud vágní, a jsou doprovázené často pouze nejasnými vyobrazeními či černobílými fotografiemi, i když jsou technicky správné. Při vyhodnocování souboru tak hraje subjektivita badatele téměř hlavní roli, a pokud není v textu patrné, na základě jakých kritérií hodnotí každý znak jako pozitivní, je téměř nemožné vyhnout se chybám, a tedy i odlišným frekvencím výskytu jednotlivých znaků. Proto byla pro srovnání výsledků této práce využita pouze disertační práce P. Velemínského (Veleminský 2000), s kterým bylo možné metodiku určování znaků konzultovat a sjednotit, a který se v československém prostředí nemetrickými znaky soustavně zabýval. Ovšemže i zde se pravděpodobně vyskytnou odchylky v určování materiálu, nicméně jejich výskyt je alespoň minimalizován.

Všechny znaky hodnotila autorka studie a seznam všech znaků je uveden v tab. 2.

Kromě nemetrických znaků byla pozornost věnována vždy také demografické a archeologické charakteristice jednotlivých skupin a snaze vypozorovat př́ípadné souvislosti mezi těmito vlastnostmi a nemetrickými znaky.

\subsubsection{Vyhodnocení dat a príbuznost}

Stěžejní nevýhodou stanovení příbuznosti na základě analýzy nemetrických znaků je fakt, že doposud neexistuje jasně definovaný systém, dle kterého by se dal přesně určit příbuzenský vztah dvou jedinců. Přesto, pokud vyjdeme z několika známých skutečností, lze dojít k poměrně relevantním závěrům. Při vyhodnocení materiálu ze satelitních pohřebišt Pohanska jsem proto vycházela $\mathrm{z}$ těchto skutečností:

- Nemetrické znaky jsou jistým způsobem dědičné, a pokud se běžně vyskytují, je to v omezené míře, specifické pro každou populaci.

- Frekvence jejich výskytu pro velkomoravskou populaci stanovil P. Velemínský ve své dizertační práci (Veleminský 2000, tab. 51) na jedincích z pohřebiště Mikulčice-Kostelisko. Ačkoliv jsou publikovány i jiné frekvence nemetrických znaků $\mathrm{z}$ velkomoravského prostředí, nejsou srovnávány s hodnoceným souborem $\mathrm{z}$ důvodů zmíněných výše (viz podkapitola „Zkoumání příbuznosti pomocí analýzy nemetrických znaků“). Vzdálenější soubory není vhodné použít, protože v každé populaci jsou frekvence výskytu znaků odlišné.

- Analýzy jedinců, u kterých je známo, že jsou příbuzní, dokazují, že některé nemetrické znaky se u nich nacházejí ve zvýšené míře 


\begin{tabular}{|c|c|}
\hline sutura metopica & processus frontalis ossis temporalis \\
\hline sutura supranasalis & processus temporalis ossis frontalis \\
\hline fissura metopica & process. parietalis ossis sphenoidalis \\
\hline ossiculum metopicum & canalis opticus partitus \\
\hline sutura parametopica & foramen ovale partitum \\
\hline incisura supratrochlearis & foramen ovale incompletum \\
\hline foramen supratrochleare & foramen spinosum incompletum \\
\hline sulcus frontalis & foramen ovale et spinosum confluens \\
\hline incisura frontalis & foramen Vesalii \\
\hline foramen frontale & processus pterygo-spinosus \\
\hline incisura supraorbitalis & processus pterygo-alaris \\
\hline foramen supraorbitale & ponticulus clinoideus medius \\
\hline spina trochlearis & ponticulus carotico-clinoideus \\
\hline foramen ethmoidale absens & ponticuli interclinoidei \\
\hline ossiculum praefrontale & taeniae interclinoidae \\
\hline ossiculum suturae coronalis & asimilatio atlantis \\
\hline lamina orbitalis partita & fovea articularis superioris bipartita \\
\hline ossiculum bregmaticum & ponticulus atlantis lateralis \\
\hline ossiculum suturae sagittalis & ponticulus atlantis posterior \\
\hline ossiculum incisurae parietalis & foramen processus transversi partitum \\
\hline os parietale partitum & foramen proccessus transversi apertum \\
\hline foramen parietale & facies articularis costalis (C7) \\
\hline foramen parietale absens & facies articularis costalis (L1) \\
\hline foramen parietale inferior & ossiculum dens axis \\
\hline depressio biparietalis circumscripta & vertebrae absentes \\
\hline processus interparietalis & vertebrae accessoriae \\
\hline ossiculum lambdae & Cranialisatio (lumbilisace) \\
\hline ossiculum suturae lambdoideae & Caudalisatio (sakralizace) \\
\hline os Incae & facies articularis sacralis access. (Sa,Co) \\
\hline sutura mendosa & spina bifida sacralis \\
\hline os Asterii & fenestratio manubrium sterni \\
\hline processus retromastoideus & fenestratio corpus sterni \\
\hline torus occipitalis & foramen suprascapulare \\
\hline foramen occipitale & ossiculum acromii \\
\hline facies condylaris bipartita & ossiculum coracoideum \\
\hline processus paracondylaris & facies articularis acromialis \\
\hline tuberculum praecondylare & facies articularis acromialis absens \\
\hline tuberculum pharyngeum & facies articularis proccesus coracoidei \\
\hline
\end{tabular}


Biologická příbuznost jedinců ze satelitních pohřebišt' Pohanska u Břeclavi ve světle analýzy nemetrických znaků

\begin{tabular}{|c|c|}
\hline fossa pharyngea & facies articularis costalis accessoria $(\mathrm{Cl})$ \\
\hline foramen condylare & fossa costoclavicularis \\
\hline canalis condylaris & processus supracondylaris \\
\hline canalis condylaris intermedius & foramen supratrochleare $(\mathrm{Hu})$ \\
\hline foramen hypoglossale bipartitum & fossa pectoralis major \\
\hline canalis hypoglossalis absens & fossa teres \\
\hline canalis hypoglossalis partitus & ossiculum styloideum radii \\
\hline foramen supracondylare & facies articularis carpalis partita (Ra) \\
\hline linea nuchae suprema & fossa bicipitis \\
\hline squama temporalis parietalis & facies articularis trochlearis partita (UI) \\
\hline ossiculum suturae squamosae & incisura radialis partita (UI) \\
\hline processus parietalis squamae temp. & ossiculum styloideum ulnae \\
\hline sutura squamomastoidea & fossa faciei lunatae \\
\hline processus mastoideus bipartitus & synostosis acetabuli incompleta \\
\hline foramen mastoideum intrasuturam & facies lunata partita (Co) \\
\hline foramen mastoideum extrasuturam & incisura faciei lunatae (Co) \\
\hline foramen tympanicum & fossa Alleni \\
\hline torus acusticus & facies Poirieri \\
\hline spina suprameatica & trochanter tertius \\
\hline foramen squamae superior & riding facet (Fe) \\
\hline depressio suprameatica & facies Charlesi \\
\hline foramen nasale absens & facies articularis condylaris media (Fe) \\
\hline ossiculum internasalis & plate formation (Fe) \\
\hline os zygomaticum partitum & fossa gastrocnemica \\
\hline fissura zygomatica transversa & fossa hypotrochanterica \\
\hline foramen zygomaticum absens & crista hypotrochanterica \\
\hline foramen zygomaticum accessorium & patella multipartita \\
\hline tuberculum marginale & incisura musculi vasti lateralis (Pa) \\
\hline tuberculum zygomaxillare & fossa musculi vasti lateralis $(\mathrm{Pa})$ \\
\hline sutura infraorbitale & retroverze \\
\hline foramen infraorbitale absens & facies articularis tibiae accessoria lateralis ( $\mathrm{Ti}$ ) \\
\hline foramen infraorbitale partitum & facies articularis tibiae accessoria medialis (Ti) \\
\hline foramen infraorbitale accessorium & fossa solei \\
\hline sutura incisiva & crista solei \\
\hline ossiculum medianum palatinum ant. & facies articularis talaris anterior et media \\
\hline torus palatinus & facies articularis talaris anterior absens \\
\hline torus maxillaris & facies articularis talaris anterior et media bipartita \\
\hline ossiculum medianum palatinum post. & facies articularis talaris anterior et media communis \\
\hline
\end{tabular}




\begin{tabular}{|l|l|}
\hline foramen mandibulare accessoria & facies articularis medialis talaris (Ta) \\
\hline foramen mentale absens & facies articularis calcanea anterior et media \\
\hline foramen mentale partitum & facies articularis calcanea anterior absens \\
\hline foramen mentale accessorium & facies articularis calcanea anterior et media bipartita \\
\hline ponticulus mylohyoideus & facies articularis calcanea anterior et media communis \\
\hline torus mandibularis & processus trochlearis tali lateralis (Ta) \\
\hline os epiptericum & processus trochlearis tali medialis (Ta) \\
\hline sutura frontotemporalis & ossiculum trigonum tali \\
\hline
\end{tabular}

Tab. 2: Výčet hodnocených nemetrických znaků. Znaky vybrány podle P. Velemínského (Velemínský et al. 2008).

Tab. 2: List od examined non-metric traits. Non-metric traits were chosen based on the work of P. Veleminsky (Velemínský et al. 2008).

(např. Suzuki - Sakai 1960). Kosterní pozůstatky otce a syna Sweerts-Šporkových vykazovaly shodu ve výskytu nemetrických znaků u 32 z celkového počtu 176 hodnocených nemetrických znaků (Veleminský - Dobisiková 1994, 69). Tento př́ílad je ovšem stanoven na novověkém materiálu s extrémně dobrou zachovalostí znaků; takové míry shody nemůžeme vzhledem $\mathrm{k}$ fragmentárnosti materiálu v podstatě nikdy dosáhnout.

- Znaky, které se přirozeně vyskytují v populaci v malé frekvenci a v analyzovaném souboru se vyskytují častěji, mohou být znakem př́ibuznosti jedinců.

Při stanovení pravděpodobné příbuznosti pro satelitní pohřebiště na Pohansku jsem musela čelit několika problémům ve vyhodnocování. Použití statistických analýz se ukázalo jako nevhodné, kvůli charakteru vstupního datového modelu. Ten byl tvořen př́liš mnoha proměnnými na př́liš málo pozorování, což spolu s fragmentárností zkoumaného materiálu vedlo k tomu, že daná data nebylo možné pro vícerozměrné statistické analýzy vůbec použít. Dalším problematickým faktorem je skutečnost, že nemetrický znak nelze hodnotit pouze jako „přítomen“, či „nepřítomen“ (což by analýzy podstatně zjednodušilo), ale i jako „nelze určit“ (část kosti, kde by se znak měl vyskytovat, chybí úplně). Do poslední kategorie bohužel spadala u posuzovaného kosterního materiálu převážná většina určovaných znaků.

Přesto bylo možné pouhým okem ve výsledcích analýzy vytipovat skupiny jedinců s výskytem více společných znaků, a tedy i potenciálně příbuzné jedince. Abych omezila vliv subjektivity badatele při hodnocení výsledků a data zobjektivizovala, vyvinula jsem metodu stanovení koeficientu potenciální prríbuznosti.

\subsubsection{Koeficient potenciální príbuznosti}

Koeficient potenciální příbuznosti představuje míru podobnosti dvou jedinců v nemetrických znacích, přičemž nebere v úvahu pouze množství společných pozitivně určených nemetrických znaků, ale zohledňuje i jejich „váhu“, tedy frekvenci výskytu v populaci. Jde vlastně o aritmetický průměr frekvencí všech pozitivních znaků společných pro oba jedince, kdy samozřejmě platí, že čím nižší je toto číslo, tím vyšší je míra jejich potenciální příbuznosti.

\begin{tabular}{|c|c|}
\hline Koeficient & $\begin{array}{l}\text { Součet frekvencí společných pozitivně } \\
\text { hodnocených znaků }\end{array}$ \\
\hline príbuznosti & $\begin{array}{l}\text { Počet společných pozitivně } \\
\text { hodnocených znaků }\end{array}$ \\
\hline
\end{tabular}


Takto definovaný koeficient byl testován na vytipovaných skupinách pravděpodobně př́ibuzných jedinců i na náhodně vybraných skupinách hrobů bez jakéhokoliv předchozího posouzení společných znaků s významným potenciálem příbuznosti. U náhodných výběrů hodnota koeficientu neklesala v průměru pod 45 a zároveň nejnižší hodnotou koeficientu bylo v jednom případě 38 (nejvyšší hodnoty překračovaly 60 ). Na základě tohoto testování byla míra koeficientu, která již může odpovídat příbuznosti, stanovena na hodnotu 36 a méně. $\mathrm{V}$ př́ípadě hraničních hodnot se přikláním $\mathrm{k}$ individuálnímu posuzování, které, ač může být lehce subjektivní, je doposud při analýze nemetrických znaků nenahraditelné.

Při více než šesti společných znacích výpočet spolehlivě posuzuje podobnost jedinců. Hranice šest byla stanovena jako více než polovina průměrného počtu všech pozitivně zjištěných nemetrických znaků na jednom jedinci mého souboru (průměrně bylo na každém jedinci zaznamenáno pouze 11 pozitivních projevů nemetrických znaků z 90 hodnotitelných). Zároveň jde o to, aby nebyla za příbuznou automaticky považována dvojice, která má společné například tři méně významné znaky, které však mají středně vysokou frekvenci (například $30 \%$ ).

Frekvence výskytu nemetrických znaků, které jsem pro výpočet koeficientu použila, byly stanoveny pro velkomoravskou populaci P. Velemínským na kosterním materiálu z pohřebišstě na lokalitě Mikulčice-Kostelisko (Veleminský 2000, tab. 51). Ačkoliv tyto frekvence mohou být zkreslené výskytem prríbuzných (a tedy i vyšší frekvencí některých „rodových“ znaků) na pohřebišti, či velikostí hodnoceného souboru, jsou chronologicky i vzdáleností pro použití pro hroby z Pohanska nejvhodnější.

\section{Výsledky}

\subsection{Lesní hrúd}

Analýza nemetrických znaků, která byla pro satelitní pohřebiště provedena, měla za úkol verifikovat, zda jde (vždy v rámci skupiny) o hroby geneticky př́buzných jedinců. Tato interpretační hypotéza byla pravděpodobně potvrzena pouze pro skupinu z polohy Lesní hrúd, kde dle koeficientu potenciální příbuznosti hroby tvořily navzájem provázané dvojice. Není bez zajímavosti, že H 21, který se vymykal pravidelné formaci ostatních hrobů, neměl s ostatními hroby z této polohy žádné společné nemetrické znaky, a to i přesto, že dochovanost tohoto jedince byla dobrá a bylo u něj možné hodnotit velké množství znaků.

$\mathrm{Z}$ archeologického hlediska bylo $\mathrm{v}$ případě Lesního hrúdu zaznamenáno velmi mělké zahloubení hrobů - jedinci byli pohřbeni v průměrné hloubce $30,75 \mathrm{~cm}$ od podloží (nejmenší údaj činí pouhých $9 \mathrm{~cm}$ ), a i poté, co připočítáme nadložní vrstvu, jde průměrně jen o $45 \mathrm{~cm}$ od původní úrovně terénu. Hroby jsou seřazeny do dvou řad s přibližně totožnou orientací na světové strany (data ziskána z terénni dokumentace uložené v archivu ÚAM FF MU na pracovišti v Pohansku u Břeclavi).

I když z pohledu analýzy nemetrických znaků a příbuznosti jedinců není hloubka hrobů nikterak důležitá, jde o situaci přinejmenším zajímavou pro chronologický vývoj lokality tento areál jistě nemohl být po pohřbení jedinců v takto mělkých hrobech nadále využíván standardním způsobem. Nerada bych v tomto směru vynášela interpretační soudy, pouze bych na tuto skutečnost ráda upozornila badatele, kteří se chronologii hradiska věnovali, věnují či budou věnovat.

Z demografického hlediska je zvláštní, že ve skupině byl pouze jeden muž, a to ve věku 18-21 let, kterého lze tedy považovat za velmi 


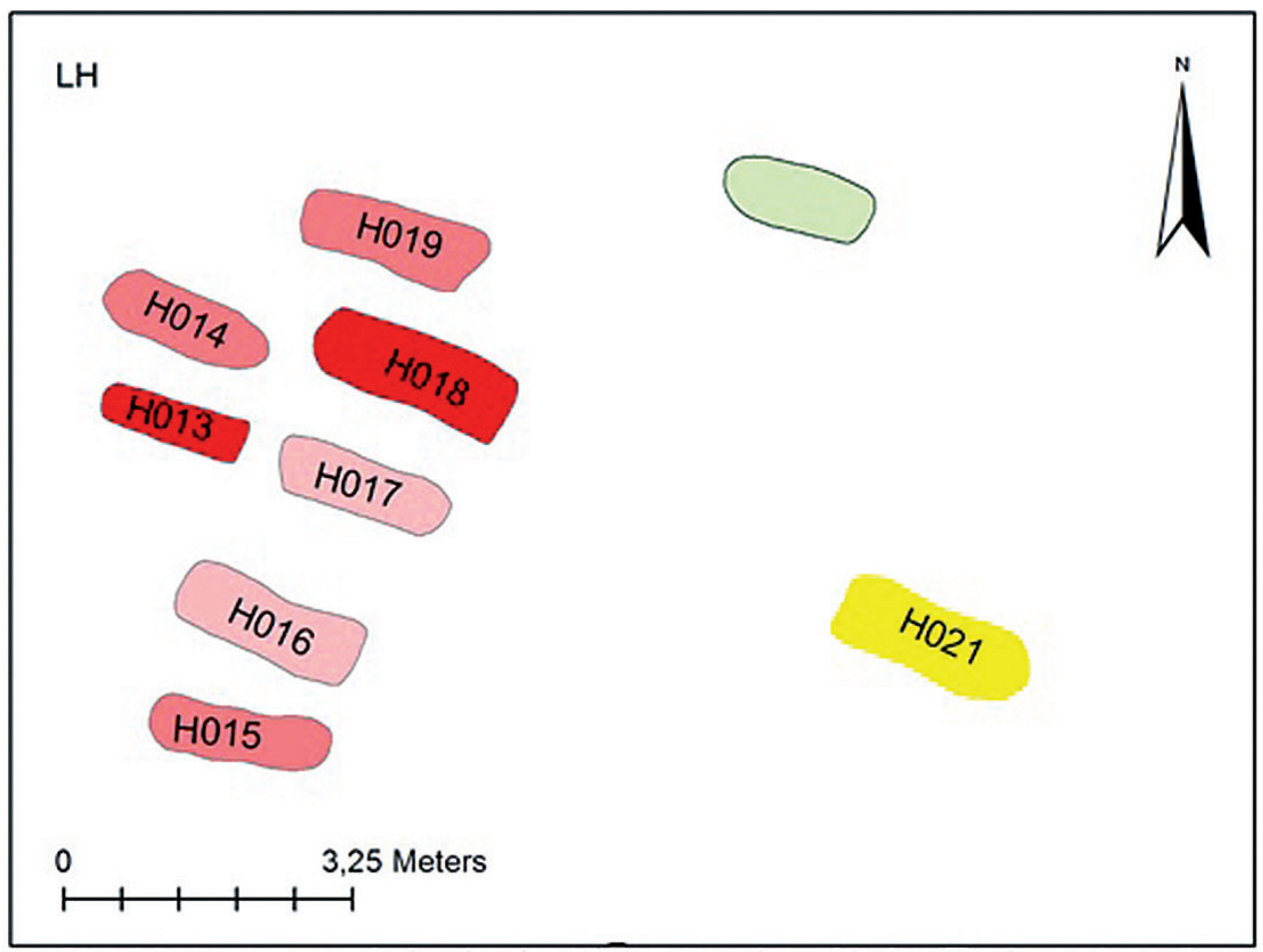

Obr. 3: Analyzovaná skupina hrobů v poloze Lesní hrúd. Vztahy znázorněny stejnou barvou.

Fig. 3: Analysed group of graves at Forest Dune site. The relationships are marked in the same colour.

\begin{tabular}{|c|l|c|l|l|}
\hline Číslo hrobu & \multicolumn{1}{|c|}{ Pohlaví } & Věk & Orientace hr. jámy & Hloubka hr. jámy [cm] \\
\hline 12 & kostra nenalezena & - & SZZ-JV & $?$ \\
\hline 13 & neurčeno & 8 & SZZ-JVV & 25 \\
\hline 14 & neurčeno & $12-15$ & SZZ-JVV & 46 \\
\hline 15 & žena & $24-30$ & SZZ-JVV & 17 \\
\hline 16 & žena & $20-40$ & SZZ-JVV & 34 \\
\hline 17 & žena & $24-30$ & SZZ-JVV & 34 \\
\hline 18 & muž & $18-21$ & SZZ-JVV & 9 \\
\hline 19 & žena & $56-65$ & SZZ-JVV & 41 \\
\hline 20 & neurčeno & 8 & nebyla zachycená & - \\
\hline 21 & žena & $49-58$ & SZZ-JVV & 40 \\
\hline
\end{tabular}

Tab. 3: Demografické údaje analyzovaných hrobů z polohy Lesní hrúd (Drozdová 2005, 69). Hloubka hrobové jámy je zde uvedena $v$ centimetrech od podloží (data získána z terénní dokumentace uložené v archivu ÚAM FF MU na pracovišti v Pohansku u Břeclavi).

Tab. 3: Demographic data of the anayzed graves from Lesni Hrud area (Drozdová 2005, 69). The depth of the graves is measured in centimeters from the original surface level. The data was acquired from the original documentation stored in the archives of UAM FF MU at Pohansko by Breclav. 

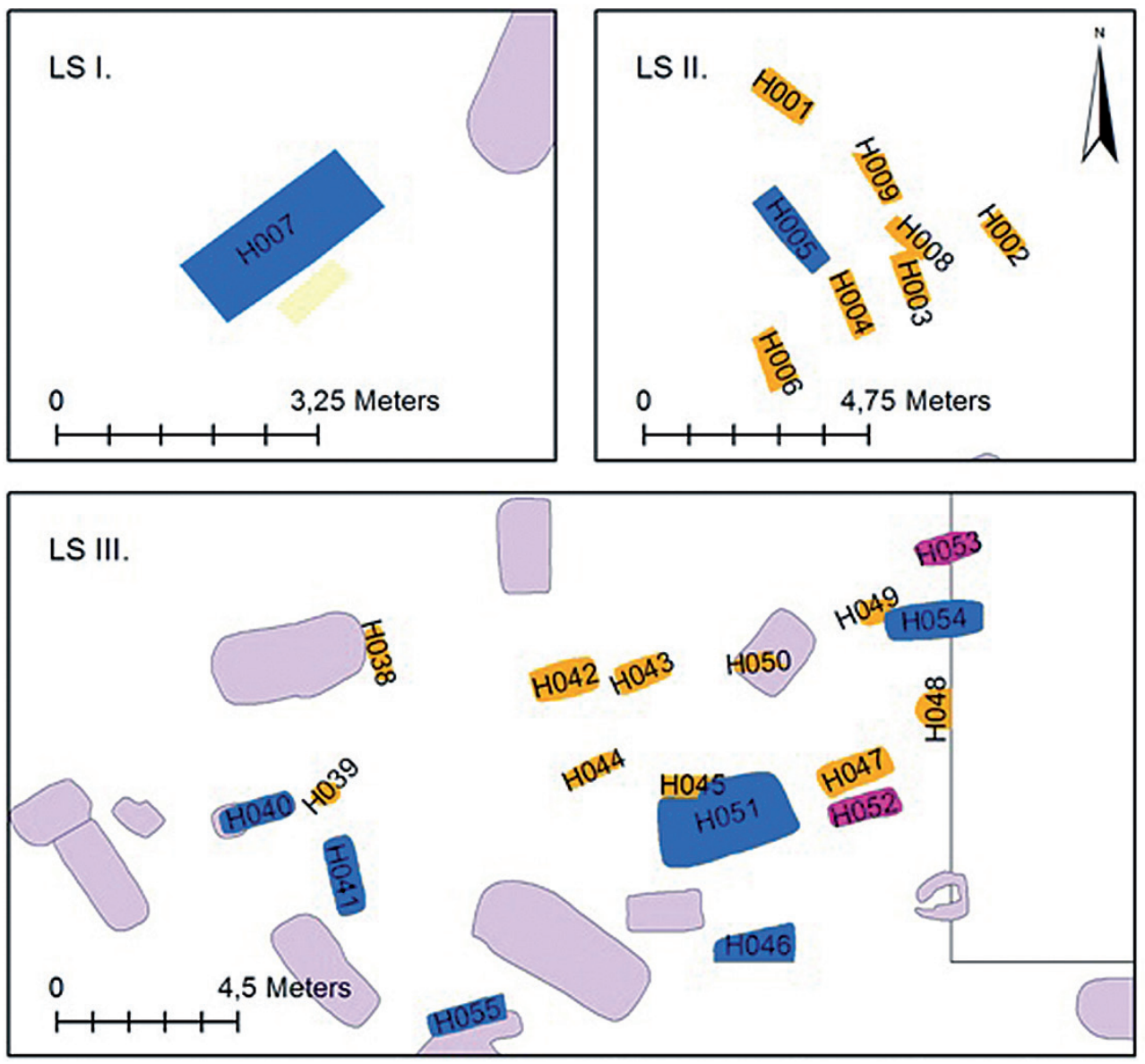

Obr. 4: Skupiny hrobů v poloze Lesní školka. Modře vyznačeni muži, růžově ženy a oranžově děti.

Fig. 4: Grave groups at Forest Nursery site. Men are marked in blue, women in pink and children in orange.

mladého dospělého, téměř ještě dítě (Drozdová 2005, 69).

Pokud v hrobech byla nalezena nějaká hrobová výbava, byla chudá. Světlou výjimku tvoří železný nůž, nalezený v H 18 (jediná mužská kostra ve skupině) a skleněné korálky z H 21 (data ziskána z terénni dokumentace uložené $v$ archivu ÚAM FF MU na pracovišti v Pohansku u Břeclavi), který byl odkryt mimo skupinovou formaci.

Pro ostatní zkoumané polohy předpoklad př́buznosti jedinců ve skupinách potvrzen ne- byl, převažují pravděpodobně příbuzenské vztahy mezi jedinci napříč skupinami. Tato skutečnost není až tak překvapivá, uvážíme-li, že jde o jedno a to samé hradisko.

\subsection{Lesní školka}

V rámci areálu Lesní školky tvořily zkoumané hroby tři prostorově izolované skupiny. Z hlediska nepopiratelné přítomnosti velkého množství výrobních zařízení v prostoru Lesní školky, 
a tedy již klasické interpretace tohoto areálu jako řemeslnický, je zajímavá skutečnost, že zde bylo pohřbeno značné množství dětí. Dětské hroby zde tvoří až dvě třetiny všech analyzovaných hrobů (Drozdová 2005, 64-67).

Hloubky hrobů se ani v tomto prrípadě neblížily standardním pohřbům na pohřebištích u prvního ani u druhého kostela na Pohansku - v Lesní školce dosahovaly průměrně $17 \mathrm{~cm}$ od podloží, tedy něco kolem $32 \mathrm{~cm}$ od úrovně původního terénu. Stejně jako v případě Lesního hrúdu, ani v Lesní školce nemají tyto hodnoty vliv na analýzu nemetrických znaků a př́ibuznost jedinců, hloubka hrobů na hranici hygienického minima by ovšem alespoň na nějakou dobu znemožnila další život v tomto areálu, a tedy to může být podnět $\mathrm{k}$ dalšímu zamyšlení.

Příbuzenské vazby uvnitř skupin v areálu Lesní školky se neukázaly být nikterak významné. Pouze v případě H 7 (osamocený hrob) a H 9 z druhé skupiny lze hovořit o pravděpodobné příbuznosti. Jako významnější se dle koeficientu potenciální př́buznosti jevila vazba mezi zmíněným H 7 a hroby H 3 a H 4 z areálu Severního předhradí.

\subsection{Jižní předhradí}

Zkoumaný vzorek z Jižního předhradí tvořilo pouze pět hrobů, H 174 - H 178. Z toho bylo možné nemetrické znaky hodnotit pouze u H 175 a H 176, nebot ve zbylých případech nebyl kosterní materiál dochován bud' vůbec, nebo byl zásadně poškozen. Dle publikovaného antropologického posudku šlo o dva muže v produktivním věku v jedné hrobové jámě (Drozdová 2005, 104).

Jedině v př́ípadě Jižního předhradí odpovídaly hloubky hrobů průměrným hloubkám hrobů na pohřebištích u kostelů. Tyto hroby také byly o poznání lépe vybaveny - H 176 obsahoval mimo jiné i ostruhy, H 177 skleněný korálek a rolničky a H 178 dva nože a fragmenty vědra
(Přichystalová 2011, 209-215). Tato hrobová výbava je ze zkoumaného celku jedna z nejbohatších.

Vezmeme-li v úvahu, že bylo možné v rámci skupiny hodnotit pouze dvě kostry navzájem, těžko lze vyvozovat závěry o pravděpodobné genetické příbuznosti celku. Není ovšem bez zajímavosti, že obě kostry ze společné hrobové jámy vykazovaly až podezřelou neshodu v nemetrických znacích - nejen, že neměly mnoho společných pozitivních výskytů znaků, ale naopak si ve většině znaků, hodnotitelných u obou jedinců, odporovaly. Analogická situace se v souboru opakovala i v př́padě dvou jedinců pohřbených do jedné hrobové jámy (10a a $10 \mathrm{~b})$ z prostoru Severního předhradí.

Nižší hodnoty koeficientu a tedy i vyšší pravděpodobnost příbuznosti vykazoval pouze $\mathrm{H}$ 176 s jedinci z Lesní školky.

\subsection{Severní předhradí}

Pro Severní předhradí bylo možné rozdělit zkoumanou množinu hrobů na dvě prostorově jasně ohraničené skupiny. V rámci obou skupin jde opět o demograficky nestandardní situaci, nebot' v prvním případě jde bez výjimky o hroby dětí doprovázené čtyřmi ženami (věk mezi 30-50 lety, 50-60 lety, 40-50 lety a žena nad 60 let), a $\mathrm{v}$ př́ípadě druhém třemi muži, přičemž dva spadají do kategorie senilis (nad 60 let) a třetí je označen jako maturus (s věkovým rozpětím 40-60 let). Nejstarší dítě z obou skupin mohlo mít maximálně sedm let (Drozdová 2005, 83-85).

Za zmínku jistě stojí i fakt, že ani v poslední hodnocené skupině nedosahují hloubky hrobů průměr známý z kostelních pohřebišt Pohanska. V tomto př́ípadě je průměrná hloubka hrobové jámy $37 \mathrm{~cm}$ od podloží, tedy cca $55 \mathrm{~cm}$ od původního povrchu (data ziskána z terénni dokumentace uložené $v$ archivu ÚAM FF MU na pracovišti v Pohansku u Břeclavi). 

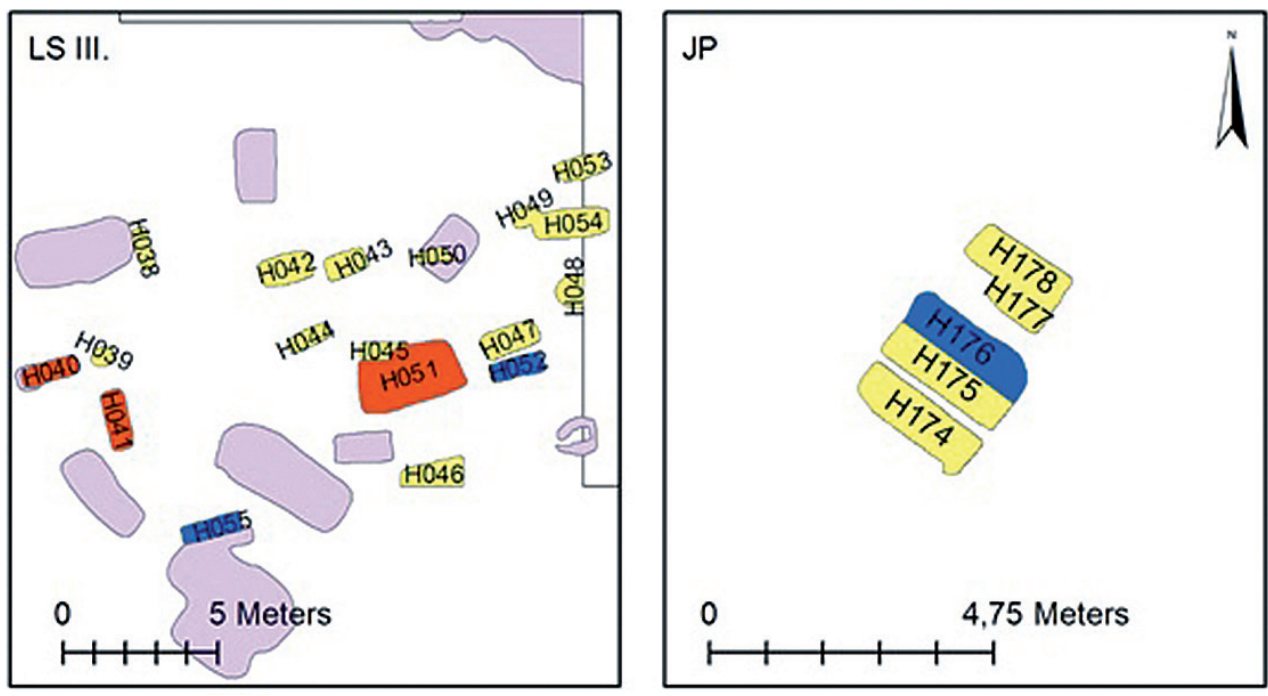

Obr. 5: Skupiny potenciálně př́buzných jedinců.

Fig. 5: Groups of potential relatives.
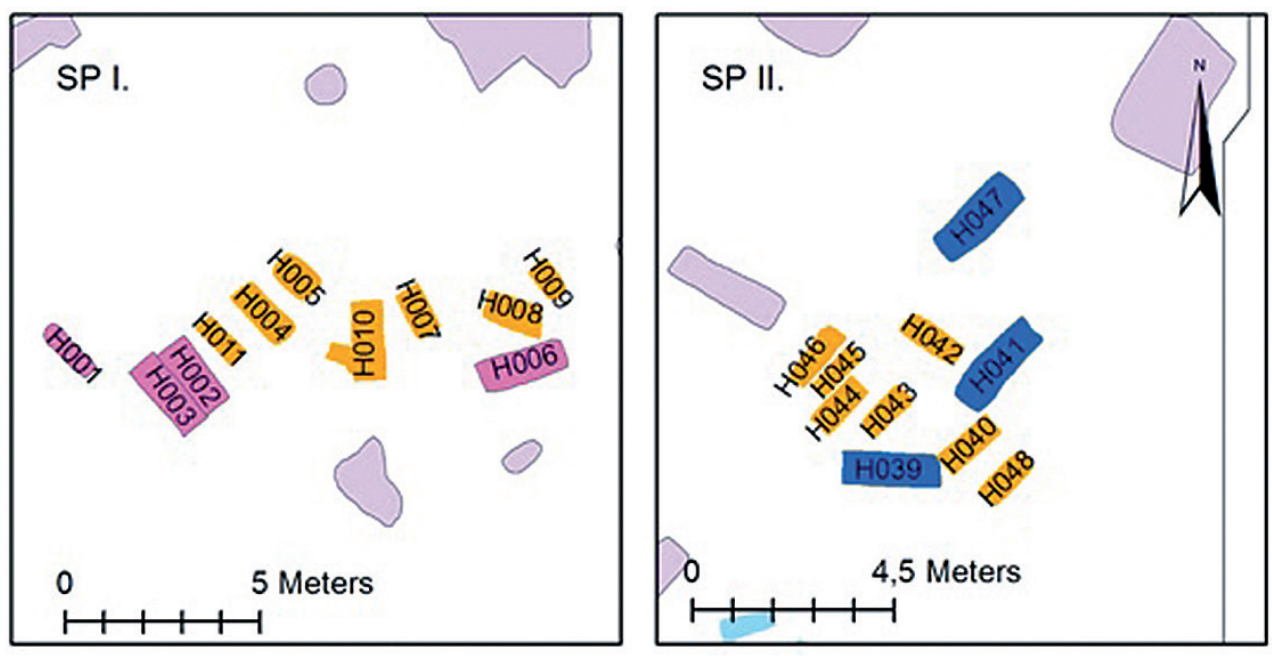

Obr. 6: Skupiny hrobů Severního předhradí. Modře vyznačeni muži, rưžově ženy a oranžově muži.

Fig. 6: Grave groups in the Northern Suburb. Men are marked in blue, women in pink and children in orange. 


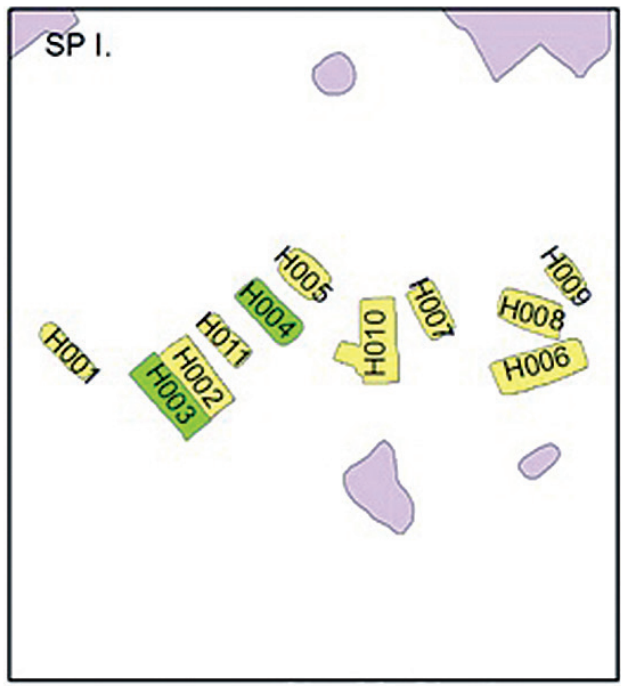

Obr. 7: Skupina potenciálně príbuzných jedinců.

Fig. 7: Group of potential relatives.

$\mathrm{V}$ rámci skupiny byli jako pravděpodobně př́ibuzní označeni jedinci z hrobu $\mathrm{H} 03$ a H 04, přičemž zvláště znaky přítomné u H 03 velmi silně korelovaly se stavem zjištěným u jedince z hrobu H 07 z polohy Lesní školka. Další vztah, který by bylo možné pro sledovaný areál navrhnout, je potenciální příbuznost jedinců $\mathrm{H}$ 10b a H 41. Kosterní materiál z obou hrobů byl ale hodně poničen, proto to nelze tvrdit s určitostí. Prostorově spolu tyto hroby nijak nesouvisí.

\section{Diskuse}

Původní hypotéza, že vždy jde o ve skupinách pochované geneticky příbuzné jedince, kterou měla za úkol studie potvrdit, se ukázala jako více než diskutabilní. S výjimkou Lesního hrúdu, kde byla pravděpodobná příbuznost $\mathrm{v}$ rámci skupiny potvrzena, ji nelze s klidným svědomím potvrdit u žádné jiné skupiny. Je třeba mít ale neustále na paměti, že nemetrické znaky jsou pouze spoluutvářeny přenesenou ge-

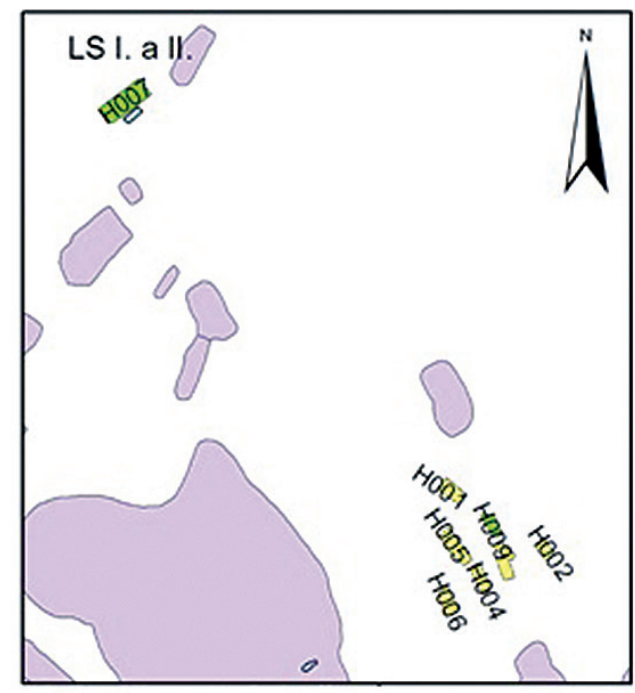

netickou informací, a tedy se nemusí za každou cenu projevit u všech jedinců, kteří pro to mají zděděné dispozice. Pochopitelně také sociální vazby (například manželství či adopce) jsou analýzou nemetrických znaků nezjistitelné a nelze tedy zjednodušeně tvrdit, že v žádném př́ípadě nejde o př́íbuzné jedince.

Analýza nemetrických znaků a výpočet koeficientu pravděpodobné př́íbuznosti se ukázaly jako metody s úspěchem využitelné i v obtížnějších podmínkách špatně dochovaného a značně degradovaného antropologického materiálu. Pokud by byla metoda přiliš necitlivá, analýza nemetrických znaků by neukázala pravděpodobné příbuzné jedince ani uvnitř skupin, ani napříč skupinami. Pokud by naopak metoda přeháněla význam i jen několika společných nemetrických znaků, daly by se očekávat falešně pozitivní výsledky napříč celým souborem. Skutečnost, že výsledky nesledují ani jeden z těchto trendů, dle mého názoru svědčí pro jejich objektivitu.

Samozřejmě i tato metoda má své nedostatky, přičemž jako nejzásadnější se v této chvíli 
jeví frekvence přirozeného výskytu nemetrických znaků v populaci, které jsou využity pro výpočet koeficientu potenciální příbuznosti. Tyto frekvence jsou populačně specifické, tzn., je třeba znát jejich hodnoty v populaci, pro jejíž jedince je koeficient potenciální příbuznosti určován. Hodnoty stanovené P. Velemínským (Veleminský 2000, tab. 51), využité pro výpočty v této práci, byly ovšem stanoveny na souboru asi 250 jedinců z pohřebiště Mikulčice-Kostelisko. Ačkoliv jde o nejlepší referenční soubor, který je doposud k dispozici, nelze ho použít zcela bez námitek. Ani v této práci totiž nebylo možné vyhodnotit všechny jedince ve všech znacích, a současně šlo o jedno pohřebiště - lze tedy předpokládat, že zde byly pochovány rodiny, u kterých se některé znaky vyskytly se zvýšenou frekvencí oproti průměru běžné velkomoravské populace. Při porovnání s hodnoceným souborem z Pohanska je skutečně možné ve frekvencích výskytu znaků pozorovat někdy mírné, někdy zásadnější rozdíly. Tento dílčí nedostatek je naštěstí možné v budoucnu jednoduše odstranit stanovením frekvencí výskytů nemetrických znaků na více geograficky vzdálenějších pohřebištích velkomoravské populace při využití stejné metodiky určování znaků, na čemž v současné době pracuji ve své disertační práci. Po zpřesnění frekvencí bude tedy možné

\section{Bibliografie}

Berry, A. C. - Berry, R. J. 1967: Epigenetic variation in the human cranium. Journal of Anatomy 101, 361-379.

Boberová, K. 2012: Genetická studie lidí z Jižního předhradí Břeclav - Pohansko. Využití genetických analýz pro určení pohlaví u fragmentárních kosterních pozůstatků. Dizertační práce na PřF MU. Brno.

Czarnetzki, A. 1971: Epigenetische Skelettmerkmale im Populationsvergleich. I. Rechts-Links- Unterschiede bilateral angelegter Merkmale. Zeitschrift für Morphologie und Anthropologie 63, 238-254. stanovit pravděpodobné příbuzenské vazby na základě výpočtu koeficientu pro každé pohřebiště či skupinu velkomoravských hrobů.

Analýzy prŕíbuznosti jsou sice $\mathrm{v}$ současné době proveditelné i jinými metodami, nicméně oproti využití hodnocení nemetrických znaků jsou nesrovnatelně cenově náročnější. Metoda nastíněná $\mathrm{v}$ této práci představuje poměrně rychlou, neinvazivní a levnou alternativu $\mathrm{k}$ jiným přírodovědným metodám, díky které bude možné určit pravděpodobnou př́íbuznost v rámci celých pohřebišt, mezi desítkami a stovkami jedinců.

Prezentovaná metoda ale do budoucna není limitována pouze velkomoravskou populací. Při dostatečně velkém vzorku kosterního materiálu jakékoliv prostorově a chronologicky ohraničené populace (pro stanovení frekvencí výskytu nemetrických znaků) bude vždy možné výpočtem koeficientu potenciální prŕíbuznosti stanovit pravděpodobné př́ibuzenské vazby mezi dvěma i více jedinci. Pro archeologii se zde tak otevírají nové možnosti ověřování hypotéz, jako naprríklad posouzení, zda jedinci v předpokládaných vládnoucích rodových liniích byli pokrevně příbuzní, či jde o sérii adoptivních potomků, zda byli prŕíbuzní jedinci na pohřebištích pohřbíváni pohromadě, či zda tzv. hroby elit mají společný genetický základ.

Dostál, B. 1970: Severovýchodní předhradí Břeclavi - Pohanska. Sborník prací Filozofické fakulty brněnské univerzity $\mathrm{E} 15,117-144$.

Dostál, B. 1982: Drobná pohřebiště a rozptýlené hroby z Břeclavi - Pohanska. Sborník prací Filozofické fakulty brněnské univerzity E 27, 135-201.

Drozdová, E. 2005: Břeclav - Pohansko VI. Slovanští obyvatelé velkomoravského hradiska Pohansko u Břeclavi (demografická a antropometrická studie). Brno.

Falconer, D. S. 1965: The inheritance of liability to certain disease, estimated from the incidence among relatives. Annals of Human Genetics. 29, 51-76. 
Finnegan, M. 1978: Non-metric variation of the infracranial skeleton. Journal of Anatomy 125, 23-37.

Grüneberg, H. 1952: Genetical studies on the skeleton of the mouse IV. Quasi-continuous variations. Journal of Genetics 51, 95-114.

Grüneberg, H. 1963: The Pathology of Development. Oxford.

Hallgrimsson, B. - Ó Donnabháin, B. - Bragi Walters, G. - Cooper, D. M. L. - Gudbjartsson, D. - Stefánsson, K. 2004: Composition of the Founding Population of Iceland: Biological Distance and Morphological Variation in Early Historic Atlantic Europe. American Journal of Physical Anthropology 124, 257-274.

Hauser, G. - De Stefano, G. F. 1989: Epigenetic variants of the human skull. Stuttgart.

Hrnčírová, M. 2003: Nemetrické a epigenetické znaky na pohřebišti okolo kostela na Pohansku u Břeclavi. Magisterská diplomová práce na PřF MU. Brno.

Krchová, K. 2004: Nemetrické a epigenetické znaky na satelitních pohřebištích Pohanska u Břeclavi. Magisterská diplomová práce na PřF MU. Brno.

Lane, R. A. 1976: The genetic meaning of a distance measure based on non-metric skeletal variants. American Journal of Physical Anthropology 44, 190-191.

Lane, R. A. 1978: Non-metric osteological variation as a function of genetic kinship (abstract). American Journal of Physical Anthropology 48, 413.

Macháček, J. 2005: Pohansko u Břeclavi. Raně středověké centrum jako socioekonomický systém. Význam, smysl a funkce. Habilitační práce na FF MU. Brno.

Ossenberg, N. S. 1969: Discontinuous morphological variation in the human cranium. Toronto - Ontario.

Prichystalová, R. 2011: Problematika pochovávania na Južnom predhradí velkomoravského hradiska Břeclav - Pohansko. Dizertační práce na FF MU. Brno.

Reinhard, R. - Rösing, F. W. 1985: Ein Literaturüberblick über Definitionen diskreter Merkmale/anatomischer Varianten am Schädel des Menschen. Ulm.

Saunders, S. R. - Popovich, F. 1978: A family study od two skeletal variants: atlas bridging and clinoid bridging. American Journal of Physical Anthropology 49, 193-204.

Sedláček, M. 1999: Příbuzenské vztahy určené na základě odontologických znaků u obyvatel hradiska Pohansko - pohřebiště okolo kostela. Magisterská diplomová práce na PřF MU. Brno.
Sjøvold, T. 1984: A report on the heritability of some cranial measurements and non-metric traits. In: G. N. van Vark, W. W. Howells (eds.), Multivariete statistical methods in Physical Anthropology, Dordrecht - Boston - Lancaster, 223-246.

Suzuki, M. - Sakai, T. 1960: A familial study of torus palatinus and torus mandibularis. American Journal of Physical Anthropology 18, 263-272.

Torgersen, J. 1963: Über Erbfaktoren für die Ausbildung von Schädelnähten und deren Aussagewert über den Hominisationsablauf. Homo 14, 16-29.

Veleminský, P. 1999: Morfologické znaky na lidské kostře. In: M. Stloukal et al. (eds.), Antropologie. Př́ručka pro studium kostry, Praha, 125-151.

Veleminský, P. 2000: Mikulčice - Kostelisko. Některé kostní projevy nespecifické zátěže a možnosti stanovení pokrevně příbuzenských vztahů na základě morfologické podobnosti. Dizertační práce na UK PřF. Praha.

Veleminský, P. - Dobisíková, M. 1994: Příbuznost a morfologie u kosterních pozůstatků. In: V. Novotný, E. Drozdová (eds.), Česká soudobá antropologie, Brno, 67-71.

Veleminský, P. - Dobisiková, M. 2005: Morphological likeness of the skeletal remains in a central European family from 17 th to 19 th century. Homo 56, 173-196.

Veleminský, P. - Dobisiková, M. - Stránská, P. - Veleminská, J. 2008: Biological diversity of non-metric traits in the Great Moravian population - the comparison of the Mikulčice power centre and its hinterland. In: P. Velemínský, L. Poláček (eds.), Studien zum Burgwall von Mikulčice VIII, Brno, 265-304.

Veleminský, P. - Likovský, J. 2013: Lidské kosterní pozůstatky z mohylového pohřebiště ve Stěbořicích. In: P. Kouřil, M. Tymonová (eds.): Slovanský mohylník ve Stěbořicích u Opavy, Brno, 223-271.

\section{Další zdroje}

Terénní dokumentace uložená v archivu ÚAM FF MU na pracovišti v Pohansku u Břeclavi

\section{Webové zdroje}

www.mapy.cz, 10.1.2019 


\section{Biological kinship estimation of the individuals found at the side cemeteries of Pohansko near Břeclav based on non-metric traits analysis}

Non-metric traits (also epigenetic, quasi-continuous or discrete traits - different names for the same characteristics) are known in professional literature since the 1950 s - 1960s when this topic has been treated by researchers like Hans Grüneberg (Grüneberg 1952, id. 1963), A. C. and R. J. Berry (Berry - Berry 1967), M. Suzuki and T. Sakai (Suzuki - Sakai 1960), N. S. Ossenberg (Ossenberg 1969) and A. Czarnetzki (Czarnetzki 1971). The fundamental treatise on cranial traits was written by Hauser and De Stefano (Hauser - De Stefano 1989), one of the crucial works concerning the postcranial skeleton is a publication by M. Finnegan (Finnegan 1978). In Czech literature, non-metric varieties were intensively treated by $\mathrm{P}$. Velemínský (e.g. Veleminský 1999, id. 2000).

Non-metric traits represent morphological anomalies on the skeleton, which meet the following criteria: high heritability, low frequency of occurrence in population, low dependency on the age and sex, and low inter-trait correlation (Reinhard - Rösing 1985). Their relatively complicated way of transmission, which is not completely clarified with humans, probably is one of the reasons why the analysis of non-metric traits has been primarily used for inter-population comparisons (e.g. Hallgrimsson et al. 2004).

This study describes the use of the analysis of non-metric traits for determination of potential family relationships between inhabitants of the early medieval stronghold Pohansko near Břeclav (Fig. 1), who were buried in the so-called satellite cemeteries. These graves were unearthed in direct connection with settlement areas and created small clearly delimited groups, which supposedly might have included family-related individuals. The analysed sample comprised 49 individuals (Tab. 1) from the sites of Forest Dune (Lesní hrúd), Forest Nursery (Lesní školka), Southern Suburb (Jižní předhradí) and Northern Suburb (Severní předhradí) (Fig. 2). The 162 analysed non-metric traits (Tab. 2) were chosen on the basis of a work by P. Velemínský and his colleagues (Veleminsky et al. 2008), who examined in this manner the not very distant site Mikulčice - Valy. Although this study does not include a comparison of both these sets of data, the analysed traits make it possible in the future.

The selected set of non-metric traits was examined by the naked eye according to standards defined by previous research (e.g. Hauser - De Stefano 1989; Finnegan 1978), with the help of wires with known diameter and insulin needles with $0.3 \mathrm{~mm}$ diameter for detection of aperture patency. Besides non-metric traits, attention was also paid to demographic and archaeological characteristics of individual groups and to possible relations between these attributes and non-metric traits.

Although the analysed skeletal remains were heavily damaged, their common non-metric traits enabled to identify potential relatives already with the naked eye. In order to make the results as objective as possible and to eliminate the subjective influence of researchers, the potential kinship coefficient was elaborated. This coefficient subsequently was manually calculated for preselected individuals with similar non-metric traits as well as for a control group, who did not exhibit any similarity at all. The potential kinship coefficient relies on frequencies of occurrence of non-metric traits in Great Moravian population. These traits were determined by $\mathrm{P}$. Velemínský (Veleminský 2000, tab. 51) in the group from Mikulčice-Kostelisko. In fact, it is an arithmetic average of frequencies of all positive traits which are common to both individuals involved. The lower this number, the higher the level of their potential kinship.

\begin{tabular}{lc}
$\begin{array}{l}\text { Potential } \\
\text { kinship }= \\
\text { coefficient }\end{array}$ & $\begin{array}{c}\text { Sum of frequencies of common } \\
\text { positively evaluated traits }\end{array}$ \\
\cline { 2 - 2 } & $\begin{array}{c}\text { Number of common positively } \\
\text { evaluated traits }\end{array}$
\end{tabular}

With a minimum of six common traits, the coefficient values in potential relatives were not higher than 36 . In a randomly chosen control sample, on the other hand, the values never were lower than 38 (this 
value was reached with only one randomly chosen pair). Average values varied around 45 .

Judging from the values of potential kinship coefficient, the individuals in the analysed group were related only in the satellite cemetery at Forest Dune site (Fig. 3). Family relationships within the remaining groups were not proved; in the vast majority of cases the potential inter-group kinship is dominant. The potential kinship coefficient revealed that the strongest relationship within the analysed set was between graves $\mathrm{H} 7$ from the area of Forest Nursery and graves $\mathrm{H} 3$ and $\mathrm{H} 4$ from the area of Northern Suburb (Fig. 7). Archaeologically seen, it is interesting that the average depth of graves at Forest Dune and Forest Nursery sites was very small and it would probably have hindered active life in these areas immediately after these individuals were buried there. Even though this fact has nothing in common with family relationships, it can be interesting for other researchers. Also remarkable is the demographic characteristic of individual groups - children's graves at the Forest Nursery site represented two thirds of analysed graves (Fig. 4) (Drozdová 2005, 64-67). Similar is the situation with Northern Suburb, where both analysed groups include children's graves. These are accompanied in one case by four adult women, the youngest among them in the age of 30-50 years, and in a second case by graves of three men, two of them in the category senilis and the youngest man 40-60 years old (Fig. 6). The oldest child from both groups was aged at most 7 years (Drozdová 2005, 83-85).
The whole analysed set also included two double graves, that is burials of two individuals in the same grave pit. Graves H 175 and H 176 were situated in the Southern Suburb (here the depth of graves corresponds to standard depth of graves in cemeteries at Pohansko near Břeclav), and graves $\mathrm{H} \mathrm{10a}$ and $\mathrm{H} \mathrm{10b}$ were discovered in the Northern Suburb. The individuals buried in these graves in Southern Suburb were men in productive age, whereas the individuals from the Northern Suburb were children (Drozdová 2005, 83; 104). Neither of the buried pairs reached the limit value 36 of the potential kinship coefficient, although the skeletal remains of men from the Southern Suburb were relatively very well preserved. The family relationship between these individuals of course cannot be definitely excluded. We also must consider the fact that natural scientific methods in archaeology are always able to reveal only possible genetic relations but no social relations such as adoption or marriage.

The analysis of non-metric traits and the determination of potential kinship coefficient in the studied material from satellite cemeteries at Pohansko near Břeclav yielded interesting and probably also relevant results. Although these methods currently are not yet perfect (this is the case with all methods which are still being developed), they are constantly being improved. I believe that this cheap and fast method will be used in the future with material not only from Great Moravia but also from many other periods from which a reference population sample will be acquired.

\section{Anna Koudelková}

- Ústav archeologie a muzeologie, Filozofická fakulta, Masarykova univerzita, A. Nováka 1, 60200 Brno, Česká republika anna.koudelkova@gmail.com 